\title{
Influence of Corporate Governance on Financial Performance in China's Information Industry
}

\author{
Li-Ling Yang
}

\author{
Economics \& Management College, Zhaoqing University City526061, Guangdong Province, China \\ Email:2596661416@qq.com
}

\begin{abstract}
How to enhance the value of enterprises through governance is a hot issue in the field of corporate governance research. This study selects the financial data of listed companies in the information transmission industry from 2010 to 2015 . Empirical results CEO duality have a positive impact on the financial performance, hypothesis 1 is supported. The independent director ratio has a negative impact on the financial performance, and the hypothesis 2 is supported. The board size has a negative impact on the financial performance. This paper suggests that enterprises should establish and improve the incentive mechanism of management. Improve the effectiveness of the board of directors and pay attention to the comprehensive literacy of board members to improve the performance of the enterprise.
\end{abstract}

Keywords: Corporate governance, CEO duality, Board size, Independent director ratio, Financial performance

\section{INTRODUCTION}

Guided by China's development of digital economy and the construction of digital China, the information transmission industry is driven by artificial intelligence and big data as the core technology, and continues to develop cloud computing, IOT, block chain and other technologies to promote the digital evolution of the industry supported by the new technology architecture. The development of information transmission industry has an important impact on China's economy [1].

There is an inseparable relationship between the structure level of the company and the financial performance of the enterprise. The results of Wen Gang (2020) show that the ownership concentration has a significant negative impact on earnings per share; the size of the board of directors has a significant positive impact on the return on net assets; and the independence of the board of directors has a significant positive impact on earnings per share [2].

In order to further improve the internal financial performance management, the corporate governance structure has been widely concerned. The most direct problem brought by the separation of ownership and management right is how to supervise and restrict the operator with control right as the owner who loses the control right, so as to realize the maximization of the owner's benefit. This paper hopes that through the research of internal governance variables and financial performance of information transmission enterprises, it can provide some empirical evidence for the development of information transmission industry in China.

\section{LITERATURE}

This paper studies the impact on corporate financial performance from three aspects of board size, CEO duality (combination of chairman and general manager) and independent director ratio.

Ma Yin and Yeon (2019) verify the influence of the internal governance structure on the enterprise value from 2015 to 2017 of listed companies in China. Study shows that board size, independent director ratio, directors holding shares ratio with enterprise value are significantly positive, independent director size is significantly negatively related to the value of the enterprise, and the CEO duality is not related to the value of the enterprise [3]. Chen Jiatian and Liang Huiting (2018) Selected listed small and medium-sized enterprises(SME) from 2009 to 2011 on the Shanghai Stock Exchange in China. The study found that the independent director ratio was positively correlated with the value of the enterprise, while the board size and CEO duality no significant relationship [4]. Guo Licai 
(2017) using the A stock listed companies of Shanghai and Shenzhen from 2012 to 2015 , the research shows that the company performance is significantly negatively correlated with board size, CEO duality and independent director ratio [5]. Zhao Xiaopeng and Hao Yaling (2015) analyzed the data of SME board listed companies from 2009 to 2013 and found that the increase of board size will reduce the performance of enterprises, and the increase of the proportion of independent directors will promote the performance of enterprises to some extent [6]. Li Tongyun (2015) using panel data of listed companies in Hubei Province from 2010 to 2012, shows that corporate performance is significantly positively correlated with board size, number of independent directors, CEO duality [7].

Khaled Elsayed(2011) pointed out that the board size positively affects the performance of the company. In addition, the board size proved to have a negative impact under the CEO duality [8]. Afzalur Rashid (2013) found that the CEO duality was negatively related to company performance [9]. Chung Wright \&Kedia (2013) research shows that the market valuation of a company's capital and R\&D investments depends largely on the analyst's follow and board composition, rather than institutional shareholding [10]. Wright and Kroll (2002) found that external independent directors influenced the intensity of R\&D investment and firm performance in 171 acquisition samples between 1993 and 1998 [11].

\section{RESEARCH METHODOLOGY}

\subsection{Research Hypothesis}

The general manager shall manage the activities of the company under the authority of the board of directors and assume the corresponding responsibilities. Tian Yunling et al., (2020) pointed out that the CEO duality is positively related to enterprise performance. They believe that managers have greater decision-making power and executive power, which can determine the allocation of major resources, promote innovation and development of enterprises, and improve performance [12]. Yang Longqian (2018) found that the CEO duality can make general manager more dedicated and more efficient [13]. This article is based on:

H1 : CEO duality was significantly correlated with financial performance.

H1a : CEO duality was significantly positively correlated with total return on assets;

H1b : CEO duality was significantly positively correlated with return on net assets;

H1c : CEO duality was significantly positively correlated with earnings per share.

Zhao Yujuan (2018) empirical evidence of China's coal listed companies from 2011 to 2016, shows that the proportion of independent directors has a negative correlation with financial performance [14]. Zhao and Wang Shanshan (2020) took the high-tech listed companies in Shanghai and Shenzhen from 2013 to 2017 as an empirical study. The higher the proportion of board independence, the lower the net profit margin of performance assets [15]. Based on this, we propose :

$\mathrm{H} 2$ : independent director ratio was significantly related to financial performance.

$\mathrm{H} 2 \mathrm{a}$ : independent director ratio was significantly negatively correlated with total return on assets;

$\mathrm{H} 2 \mathrm{~b}$ : independent director ratio was significantly negatively correlated with the return on net assets;

$\mathrm{H} 2 \mathrm{c}$ : independent director ratio was significantly negatively correlated with earnings per share.

The decision-making and supervision of the company are closely related to the size of the board of directors. The larger the size of the board of directors, the more directors representing the interests of shareholders. Daniel A.Rogers (2002) suggest that a smaller board can help make more efficient decisions on uncertain matters in an unstable economic or technological environment [16]. Shi Ruixin (2019) selected 56 listed companies in the information technology industry from 2011 to 2017 to demonstrate that there is a negative correlation between board size and operating performance [17]. Tao Kylie (2018) selected listed companies in the software and information technology services industry, suggesting that board size may increase agency costs and have a significant negative impact on operating performance [18]. Thus, we propose:

H3: board size was significantly related to financial performance.

H3a : board size was significantly negatively correlated with total return on assets;

$\mathrm{H} 3 \mathrm{~b}$ : board size was significantly negatively correlated with the return on net assets;

$\mathrm{H} 3 \mathrm{c}$ : board size was significantly negatively correlated with earnings per share.

\subsection{Data Source and Variable Definition}

Data from Taiwan Economic Journal (TEJ) Mainland database information transmission industry 2010-2015 corporate governance and financial data, excluding incomplete corporate data, a total of 701 sample data.

Independent variables:

(1) CEO duality: integration of two jobs, virtual variable with 1 concurrent and 0 non concurrent 
(2) Independent director ratio: proportion of independent directors to directors in the current year

(3) Board size: total number of board members (chairman + vice-chairman + executive director + general director)

Dependent variables:

(1) $\mathrm{ROA}=($ net after-tax profit/average total assets $) * 100$ per cent

(2) $\mathrm{ROE}=$ (net after after tax/average shareholder equity) $* 100$ per cent

(3) $\mathrm{EPS}=$ (net after-tax profit - on special shares)/ number of common shares in circulation

\subsection{Return Model}

$$
\begin{gathered}
R O A_{i, t}=\alpha_{0}+\alpha_{1} \mathrm{DB}_{i, t}+\alpha_{2} \mathrm{IB}_{i, t}+\alpha_{3} \mathrm{BS}_{i, t}+\varepsilon_{\mathrm{i}, \mathrm{t}} \\
R O E_{i, t}=\beta_{0}+\beta_{1} \mathrm{DB}_{i, t}+\beta_{2} \mathrm{IB}_{i, t}+\beta_{3} \mathrm{BS}_{i, t}+\varepsilon_{\mathrm{i}, \mathrm{t}} \\
E P S_{i, t}=\gamma_{0}+\gamma_{1} \mathrm{DB}_{i, t}+\gamma_{2} \mathrm{IB}_{i, t}+\gamma_{3} \mathrm{BS}_{i, t}+\varepsilon_{\mathrm{i}, \mathrm{t}}
\end{gathered}
$$

There is,

DB : CEO Duality ;

IB : Independent Directors

BS : Board size ;

ROA : Total Assets Rate

ROE : Net Assets Rate; EPS : Earnings per share

i : Company;

$$
\mathrm{t}: \text { years }
$$

$\alpha_{0}, \beta_{0}, \gamma_{0}:$ Constant term

$\varepsilon$ : error items

\section{EMPIRICAL RESULTS}

\subsection{Descriptive Statistics}

Descriptive statistics of variables show that the average of CEO duality is 0.490 , the average of independent director ratio is 27.04 and the average of board size is 12.08 . Pearson correlation coefficient, CEO duality and ROA correlation coefficient is .066 to $10 \%$ statistical significance, CEO duality and EPS correlation coefficient is .064 to $10 \%$ statistical significant level. Independent director ratio correlation coefficient between ROE is -.970 to 5\% statistical significance, and with the EPS correlation coefficient is -.073 to $10 \%$ statistical significant level. All independent variables have a tolerance greater than 0.5 and each independent variable VIF value less than 10 , thus there is no serious col-linearity between independent variables.

\subsection{Regression Analysis of Board Composition and Financial Performance}

Table 1 was the regression analysis results of the impact of board composition on financial performance.

Panel A. was the impact of board composition on ROA. CEO duality the regression coefficient was 1.770 , CEO duality was significantly positively correlated with ROA, up to $10 \%$ statistical significance level, the hypothesis H1a was supported. The regression coefficient of the independent director ratio was -1.918 , and the independent director ratio had a significant negative correlation with the ROA, reaching $10 \%$ statistical significant level, hypothesis $\mathrm{H} 1 \mathrm{~b}$ was supported. The regression coefficient of board size was -1.628 , and the board size was negatively correlated with ROA, which was consistent with our hypothesis $\mathrm{H} 1 \mathrm{c}$, but not up to $5 \%$ significant level.

Panel B. was the impact of board composition on ROE. CEO duality the regression coefficient was .050 , CEO duality was positively correlated with ROE, which was consistent with our hypothesis $\mathrm{H} 2 \mathrm{a}$, but not up to $5 \%$ significant level. The regression coefficient of the independent director ratio was -2.476 , and the independent director ratio had a significant negative correlation with the ROE, up to 5\% significant level, hypothesis $\mathrm{H} 2 \mathrm{~b}$ was supported. The regression coefficient of board size was -. 036, and the board size was negatively correlated with ROE, which was consistent with our hypothesis $\mathrm{H} 2 \mathrm{c}$, but not up to $5 \%$ significant level.

Panel C. was the impact of board composition on EPS. CEO duality the regression coefficient was 1.772 , CEO duality was positively correlated with EPS, up to $10 \%$ statistical significance, hypothesis $\mathrm{H} 3 \mathrm{a}$ was supported. The regression coefficient of the independent director ratio was -2.029 , and the independent director ratio had a significant negative correlation with the EPS, up to $5 \%$ statistical significance, hypothesis $\mathrm{H} 3 \mathrm{~b}$ was supported. The regression coefficient of board size was -. 389, and the board size was negatively correlated with EPS, which was consistent with our hypothesis $\mathrm{H} 3 \mathrm{c}$, but not up to $5 \%$ significant level.

\begin{tabular}{|c|c|c|c|c|}
\hline \multicolumn{5}{|c|}{$R O E_{i, t}=\beta_{0}+\beta_{1} \mathrm{DB}_{i, t}+\beta_{2} \mathrm{IB}_{i, t}+\beta_{3} \mathrm{BS}_{i, t}+\varepsilon_{\mathrm{i}, \mathrm{t}}$} \\
\hline (constant) & & & 455 & .000 \\
\hline DB & + & .002 & .050 & 960 \\
\hline
\end{tabular}

Table 1. Board Composition on Financial Performance

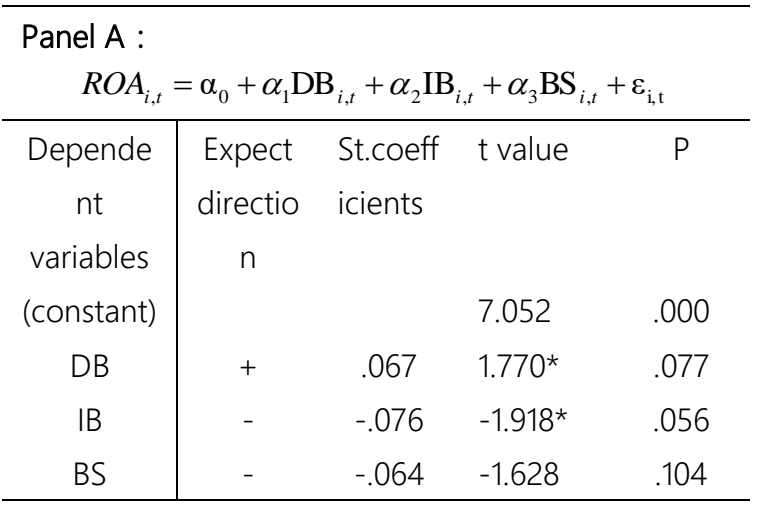

Panel B : 


\begin{tabular}{|c|c|c|c|c|}
\hline IB & - & -.098 & $-2.476^{\star \star}$ & .014 \\
\hline BS & - & -.001 & -0.036 & .971 \\
\hline \multicolumn{5}{|l|}{ Panel C : } \\
\hline \multicolumn{5}{|c|}{$E P S_{i, t}=\gamma_{0}+\gamma_{1} \mathrm{DB}_{i, t}+\gamma_{2} \mathrm{IB}_{i, t}+\gamma_{3} \mathrm{BS}_{i, t}+\varepsilon_{\mathrm{i}, \mathrm{t}}$} \\
\hline (constant) & & & 5.373 & .000 \\
\hline DB & + & .067 & $1.772^{*}$ & .077 \\
\hline $\mathrm{IB}$ & - & -.080 & $-2.029^{* *}$ & .043 \\
\hline BS & - & -.015 & -.389 & .698 \\
\hline \multicolumn{5}{|c|}{ Note $: *: 0.05<\mathrm{P}<0.1 ; * 0.01<\mathrm{P}<0.05 ; *: \mathrm{P}$ value $: 0.01$} \\
\hline \multicolumn{5}{|c|}{ DB : CEO Duality; IB : Independent Directors ratio; } \\
\hline \multicolumn{5}{|c|}{ BS : Board Size; ROA : total return on assets; ROE : } \\
\hline
\end{tabular}

\section{CONCLUSIONS}

The internal governance mechanism of a company was closely related to its operating performance. This paper took China's information transmission industry as an example to explore the impact of corporate governance variables on the financial performance of enterprises. The research conclusions of this paper were as follows:

1. The duality of CEO had a positive impact on the financial performance of the company. The combination of the two positions could promote the general manager to be more dedicated and effectively enhance their enthusiasm to create benefits for the company.

2. The proportion of independent directors had a negative impact on the financial performance of the enterprise. Independent directors did not participate in the internal operation of the enterprise and had limited understanding of the business characteristics of the enterprise and the external environment of the industry in which the enterprise was located, so they could not improve the financial performance.

3. The size of the board of directors had a negative impact on the financial performance of enterprises. The increase of the size of the board of directors would increase the communication cost of the board of directors and reduce its decision-making efficiency.

4. Establish the incentive mechanism of the management, improve the effectiveness of the board of directors, pay attention to the comprehensive quality of the board members, and improve the internal governance.

\section{REFERENCES}

[1] Zhao Xitong, Reshaping Financial Services with Innovative Application of Emerging Technologies and Promoting the Digital Strategic Transformation of Financial Industry. China Financial Computer, 2020(08):17-20.

[2] Wen Gang, Empirical Research on the Relationship between Corporate Governance Structure and Financial Performance of China's Listed Commercial Banks.The marketing world, 2020 (34) : 132-135.

[3] Ma Yin and Li Yan, Research on the influence of internal governance structure of listed companies on enterprise value . Value Engineering, 2019,38(35):1-4.

[4] Chen Jiatian and Liang Huiting, The influence of board structure on business performance. Journal of Xinyu University,2018,23(03):32-37.

[5] Guo Li. ,An empirical study on the correlation between board characteristics and corporate performance. Journal of Weifang University, 2017, 17(04):32-37.

[6] Zhao Xiaopeng and Hao Yaling, The proportion of independent directors, board size and enterprise performance . Journal of Zhengzhou Institute of Aeronautical Industry Management, 2015, 33(04):63-68.

[7] Li Tong, An Empirical Study on the Relationship between Board Characteristics and Firm Performance -- A Case Study of Listed Companies in Huazhong. Contemporary Economics, 2015(08): 15-18.

[8] Khaled Elsayed, Board size and corporate performance: the missing role of board leadership structure.Journal of Management and Governance, 2011, (15): :415.

[9]Afzalur Rashid, CEO duality and agency cost:evidence from Bangladesh.Journal of Management and Governance, 2013.

[10]Kee H. Chung, Peter Wright and Ben Kedia, Corporate governance and market valuation of capital and R\&D investments.Review of Financial Economics.2013 (2) .

[11]Wright P., Kroll M. and Elenkov D., Acquisition returns, increase in firm size, and chief executive officer compensation:The moderating role of monitoring. The Academic of Management Journal, 2002 (3) .

[12]Tian Yunling, Liang Jiling and Chen Xiaotang, The research on the technology innovation, corporate governance and enterprise performance: Based on the data of manufacturing companies in Chaoshan region.Business Accounting,2020(13):43-46.

[13] Yang LongQian, Research on the Impact of Management Power on Financial Performance of Listed Companies in China. Shenyang Aerospace University,2018. 
[14] Zhao Yujun, The impact of corporate governance on diversification strategy and financial performance. Shanxi University of Finance and Economics, 2018.

[15] Zhao Hongyang and Wang Shanshan, Research on the influence of board independence on corporate performance of high-tech enterprises. Contemporary Economy,2020(11):97-99.

[16] Daniel A. Rogers, Does executive Portfolio structure affects risk management. Journal of Banking Finance,2002.

[17] Ruixin Shi, Board governance, R\&D investment and business performance. $\mathrm{Xi}$ 'an University of Technology,2019.

[18] Kailai, T., The impact of information technology on the performance of public companies . North University of China,2018 